\title{
Ibuprofen for neuroprotection after cerebral ischemia
}

\author{
Yusuke Iwata, MD, ${ }^{\mathrm{a}}$ Olivier Nicole, $\mathrm{PhD},{ }^{\mathrm{b}}$ David Zurakowski, $\mathrm{PhD},{ }^{\mathrm{a}}$ Toru Okamura, $\mathrm{MD},{ }^{\mathrm{a}}$ and \\ Richard A. Jonas, MD ${ }^{\mathrm{a}}$
}

Objective: Ibuprofen has been shown to reduce cerebral ischemic injury, such as may occur after deep hypothermic circulatory arrest. We investigated whether ibuprofen has direct protective effects against excitotoxic neuronal injury, as may be seen after cerebral ischemia, by using a cell culture model.

\begin{abstract}
Methods: Mixed cortical cultures containing neuronal and glial cells were prepared from fetal mice at 13 to 15 days gestation, plated on a layer of confluent astrocytes from 1- to 3-day-old postnatal pups. Near-pure neuronal cultures containing less than $5 \%$ astrocytes were obtained from mice of the same gestational stage. Slowly triggered excitotoxic injury was induced at $37^{\circ} \mathrm{C}$ by 24 -hour exposure to $12.5 \mu \mathrm{mol} / \mathrm{L} \mathrm{N}$-methyl-D-aspartate or 50 $\mu \mathrm{mol} / \mathrm{L}$ kainate. Neuronal death was quantified by release of lactate dehydrogenase from damaged cells. Data were analyzed using 1-way analysis of variance with Tukey post hoc multiple comparisons.
\end{abstract}

Results: In mixed cultures, ibuprofen concentrations of $25 \mu \mathrm{g} / \mathrm{mL}, 50 \mu \mathrm{g} / \mathrm{mL}$, and $100 \mu \mathrm{g} / \mathrm{mL}$ all significantly reduced N-methyl-D-aspartate-induced neuronal cell death from $74.5 \%$ to $56.1 \%, 38.7 \%$, and $12.3 \%$, respectively, revealing a strong dose response $(P<.001)$. In near-pure cultures, ibuprofen at a concentration of $25 \mu \mathrm{g} /$ $\mathrm{mL}$ failed to protect neurons, indicating that the neuroprotective effects of ibuprofen require interaction with glial cells. Furthermore, ibuprofen at $100 \mu \mathrm{g} / \mathrm{mL}$ was not protective against neuronal cell death induced by kainate exitotoxicity in near-pure culture but was effective in mixed cultures.

Conclusion: Ibuprofen provides neuroprotection through glial cells against excitotoxic neuronal injury caused by glutamatergic excitotoxicity after cerebral ischemia as demonstrated by reduced neuronal cell death in mixed cell cultures. Further studies are needed to evaluate the potential of ibuprofen to reduce neurologic injury in patients experiencing an hypoxic/ischemic insult. (J Thorac Cardiovasc Surg 2010;139:489-93)

Low-flow cardiopulmonary bypass and deep hypothermic circulatory arrest are used to facilitate pediatric cardiac surgery, although they carry a risk of ischemic brain damage. There are also deleterious effects of cardiopulmonary bypass, such as inflammation, which may exacerbate ischemic brain injury. Ibuprofen is a nonsteroidal anti-inflammatory drug that is widely used to reduce pain, fever, and inflammation. The drug inhibits cyclooxygenase and activates peroxisome proliferator-activated receptors; both of these actions result in reduced inflammation. ${ }^{1-3}$ Ibuprofen has been shown to reduce cerebral ischemic injury and infarct size, such as may occur after deep hypothermic circulatory arrest. ${ }^{4,5}$ Ibuprofen has been reported to improve cerebral blood flow after global cerebral ischemia and to restore cerebral metabolism after cerebral traumatic injury. ${ }^{6,7}$

\footnotetext{
From the Children's National Heart Institute, ${ }^{\text {a }}$ Children's National Medical Center, Washington, DC, and UMR-CNRS $6185,{ }^{\mathrm{b}}$ Université Caen, Caen, France.

Disclosures: None.

Supported by National Institutes of Health R01HL060922.

Presented at the 16th Annual Meeting of the Asian Society for Cardiovascular and Thoracic Surgery, March 15, 2008, Singapore.

Received for publication July 21, 2008; revisions received April 23, 2009; accepted for publication May 18, 2009; available ahead of print Oct 26, 2009.

Address for reprints: Richard A. Jonas, MD, Children's National Heart Institute, Children's National Medical Center, 111 Michigan Avenue, NW, Washington, DC 20010 (E-mail: rjonas@cnmc.org).

0022-5223/\$36.00

Copyright (c) 2010 by The American Association for Thoracic Surgery doi:10.1016/j.jtcvs.2009.05.049
}

It is well known that ischemia can cause neuronal cell death through the mechanism of glutamatergic excitotoxicity. An ischemic insult initially impairs glutamate transportation at the postsynaptic level and increases extracellular glutamate levels, resulting in glutamatergic excitotoxicity, which is excessive neuronal excitation mediated by excessive calcium influx. Thus, neurologic problems after cardiac surgery, such as may occur with circulatory arrest, embolic injury, or low-flow states, may be a result of excitotoxicity after cerebral ischemia.

Glutamate is the principal neurotransmitter at the majority of synapses throughout the brain and spinal cord. N-methylD-aspartate (NMDA), AMPA, and kainate are glutamate receptor subtypes defined by their response to these agents; the NMDA pathway causes neuronal injury more rapidly than the AMPA or kainate pathway, reflecting a greater ability to induce calcium influx. Rapidly triggered excitotoxicity can be separated into 2 components: (1) immediate neuronal cell swelling induced by the influx of extracellular $\mathrm{Na}$ and (2) delayed neuronal cell degeneration induced by excessive Ca influx. AMPA, kainate, and NMDA receptors all contribute to the neuronal cell swelling seen with excitotoxic injury. In contrast, NMDA receptor activation is necessary and sufficient to induce delayed neuronal cell degeneration. Although either the acute cell swelling or delayed neuronal cell degeneration can alone produce irreversible neuronal injury, under certain conditions the majority of cells can 


\section{Abbreviations and Acronyms \\ DIV = days in vitro \\ $\mathrm{LDH}=$ lactate dehydrogenase \\ NMDA $=\mathrm{N}$-methyl-D-aspartate}

recover and survive from cell swelling. Generally most cortical neurons die through delayed neuronal degeneration. ${ }^{8}$

The purpose of the current study was to investigate whether ibuprofen has direct neuroprotective effects against excitotoxic neuronal cell death induced by NMDA and kainate using a neuronal cell culture model.

\section{MATERIALS AND METHODS Near-Pure Neuronal Cultures}

Near-pure neuronal cultures containing less than 5\% astrocytes were obtained from fetal mice at 13 to 15 days gestation (Taconic, Rockville, Md). Dissociated cortical cells in plating medium of media stock (Dulbecco's modified Eagle's medium with $25 \mathrm{mmol} / \mathrm{L}$ glucose; Sigma, St Louis, MO) supplemented with 5\% fetal bovine serum (Gibco, Carlsbad, Calif), $5 \%$ horse serum (Gibco), and $2 \mathrm{mmol} / \mathrm{L}$ glutamine (Sigma) were plated in 24-well plates coated with poly-D-lysine $(0.1 \mathrm{mg} / \mathrm{dL}$; Invitrogen, Carlsbad, Calif) and laminin $(0.02 \mathrm{mg} / \mathrm{mL}$; Invitrogen). After 3 days in vitro (DIV), non-neuronal cell division was halted by exposure to $10 \mu \mathrm{mol} / \mathrm{L} \mathrm{cy-}$ tosine arabinoside (Ara-C; Sigma). There was no further exchange of the media except adding Dulbecco's modified Eagle's medium for evaporation. After 12 DIV, cultures did not need the presence of serum to survive. They were shifted to a maintenance medium identical to plating medium but lack- ing serum. All cultures were kept at $37^{\circ} \mathrm{C}$ in a humidified $5 \% \mathrm{CO}_{2}$ incubator. Cultures were used after 13 to 14 DIV for excitotoxic injury. ${ }^{9}$

\section{Glial Cultures}

Glial cell cultures were prepared from 1- to 3-day-old postnatal mice (1-3 days after birth from Taconic, Rockville, Md). Dissociated cortical cells were plated in 24-well plates previously coated with poly-D-lysine $(0.1 \mathrm{mg} / \mathrm{dL})$ using a plating medium of media stock supplemented with $10 \%$ horse serum, $10 \%$ fetal bovine serum, and $2 \mathrm{mmol} / \mathrm{L}$ glutamine. Cultures were kept at $37^{\circ} \mathrm{C}$ in a humidified $5 \% \mathrm{CO}_{2}$-containing atmosphere until they reached confluency, 7 to 14 DIV. Confluent cultures were then used as a support for mixed cultures. ${ }^{9}$

\section{Mixed Cortical Cultures}

Mixed cortical cultures containing both neurons and astrocytes were prepared from fetal mice at 13 to 15 days gestation. Dissociated cortical cells were plated in 24 wells on a layer of confluent astrocytes, using plating medium supplemented with $5 \%$ horse serum, $5 \%$ fetal bovine serum, and 2 $\mathrm{mmol} / \mathrm{L}$ glutamine. After $7 \mathrm{DIV}$, non-neuronal cell division was halted by a 2 to 3 days of exposure to $10 \mu \mathrm{mol} / \mathrm{L}$ Ara-C. Subsequent partial medium replacement was performed twice per week, and after 12 DIV, cultures were shifted to a maintenance medium identical to plating medium although lacking serum because neurons survive without it. Experiments were performed on cortical cultures after 13 to 14 DIV. ${ }^{9}$

\section{Slowly Triggered Excitotoxicity}

Because lower levels of glutamate exposure induce delayed neuronal cell death in most cortical neurons, slowly triggered excitotoxicity was induced at $37^{\circ} \mathrm{C}$ by 24 -hour exposure to $12.5 \mu \mathrm{mol} / \mathrm{L}$ NMDA or $50 \mu \mathrm{mol} / \mathrm{L}$ kainate as an excitotoxin in media stock supplemented with $10 \mu \mathrm{mol} / \mathrm{L}$ glycine. These concentrations do not influence glial cells; $10 \mu \mathrm{mol} / \mathrm{L}$ MK-801 was always added concurrently with kainate to block secondary NMDA receptor
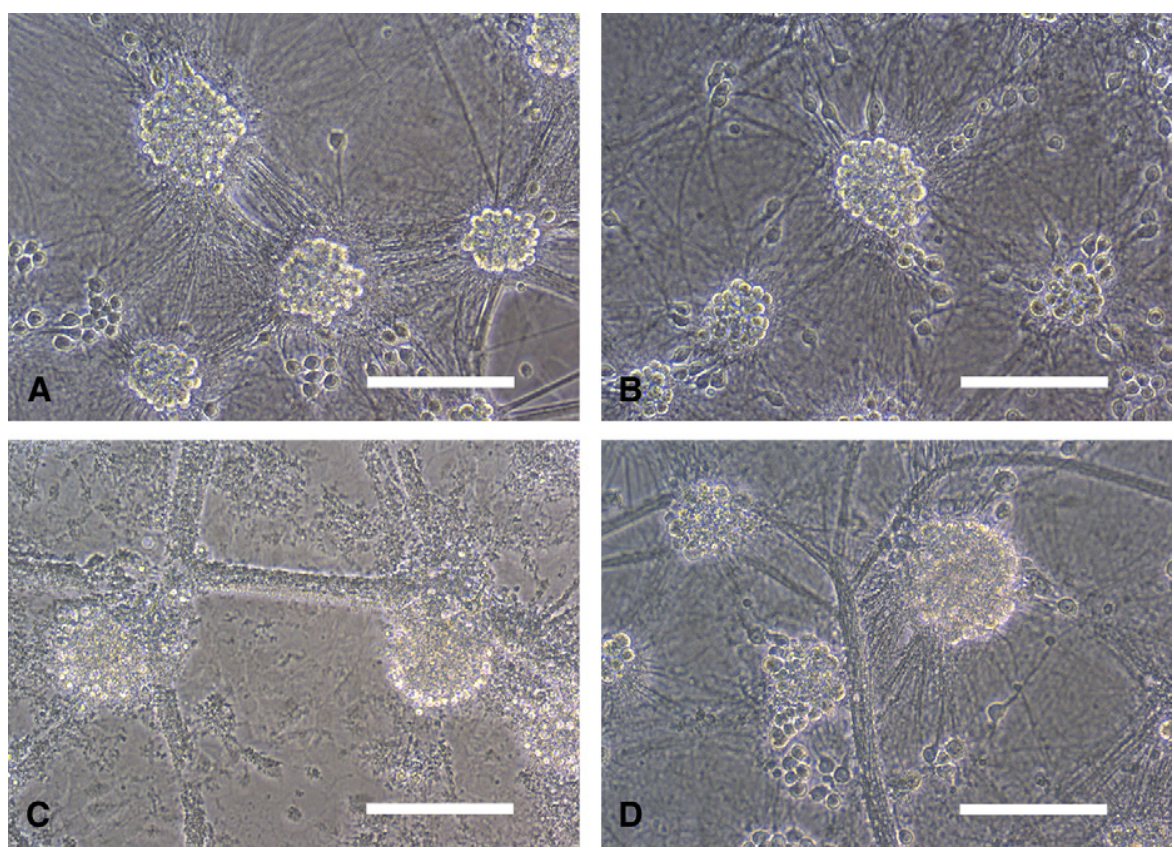

FIGURE 1. A, Sham wash (mixed cortical cultures). B, Ibuprofen $(100 \mu \mathrm{g} / \mathrm{mL})$ alone. C, Mixed cortical cultures were exposed to $12.5 \mu \mathrm{mol} / \mathrm{L}$ NMDA for 24 hours and demonstrated an acute swelling of neuronal cell bodies followed by a widespread necrotic neuronal degeneration resulting in disrupted neurons and segmentalized neuritis. D, Ibuprofen at a concentration of $100 \mu \mathrm{g} / \mathrm{mL}$ was co-applied in the medium with excitotoxin (NMDA). Ibuprofen preserved neuronal cells and protected neurites. Original magnification is $200 \times$. Scale bars $=100 \mu \mathrm{m}$. NMDA, N-methyl-D-aspartate; $I b$, ibuprofen. 


\section{Excitotoxicity by NMDA in Mixed Culture}

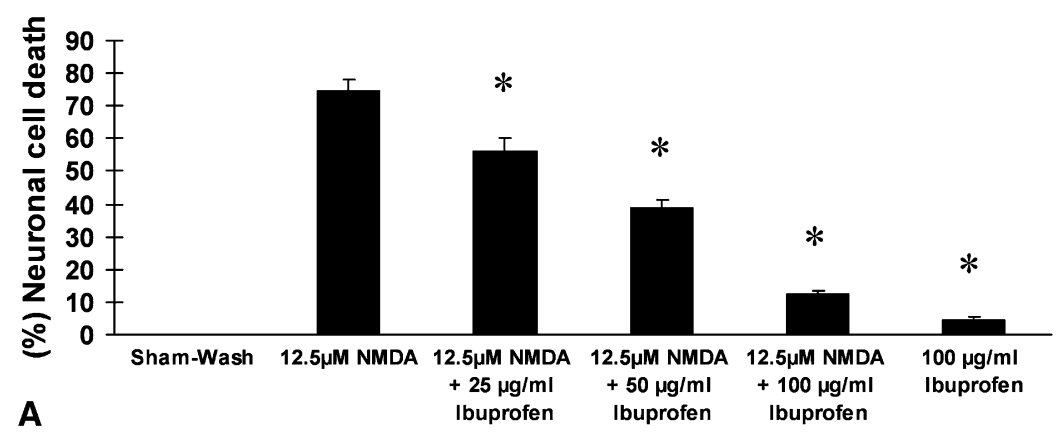

\section{Excitotoxicity by NMDA in Near-Pure Culture}

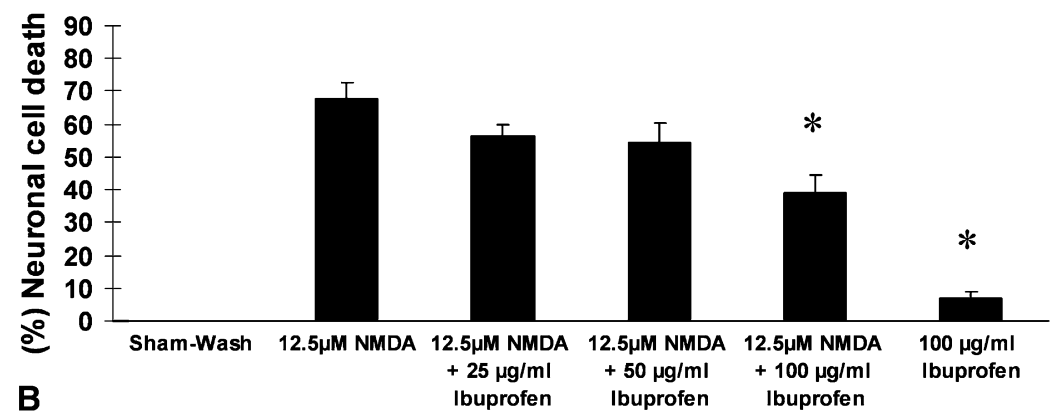

FIGURE 2. Exposure to $12.5 \mu \mathrm{mol} / \mathrm{L}$ NMDA revealed approximately $70 \%$ neuronal cell death by LDH assay measuring LDH levels in bathing medium in both cultures. Ibuprofen at a concentration of $25 \mu \mathrm{g} / \mathrm{mL}, 50 \mu \mathrm{g} / \mathrm{mL}$, and $100 \mu \mathrm{g} / \mathrm{mL}$ reduced neuronal cell death significantly from $74.5 \% \pm 3.8 \%$ to $56.1 \% \pm$ $4.0 \%, 38.7 \% \pm 2.8 \%$, and $12.3 \% \pm 1.4 \%$ in mixed cultures, respectively, revealing a strong dose response $(P<.001)$. However low-concentration ibuprofen failed to protect neurons in near-pure cultures. A, Mixed cultures. B, Near-pure cultures. *Significantly different from NMDA alone by analysis of variance with Tukey correction (mean \pm standard error).

activation. ${ }^{9}$ Ibuprofen was co-applied at 3 different concentrations, $25 \mu \mathrm{g}$ / $\mathrm{mL}, 50 \mu \mathrm{g} / \mathrm{mL}$, or $100 \mu \mathrm{g} / \mathrm{mL}$, with the excitotoxin and left for 24 hours in the bathing medium. A clinically effective concentration of ibuprofen is between 25 and $100 \mu \mathrm{g} / \mathrm{mL}$ because the inhibitory effect of ibuprofen on neutrophil activation and migration generally occurs at concentrations greater than $50 \mu \mathrm{g} / \mathrm{mL}^{10}$

\section{Assessment of Neuronal Cell Death}

The percentage of neuronal cell death was calculated by lactate dehydrogenase (LDH) assay, which is a standard method that is widely applied for quantitation of cell death in neuronal cell culture. ${ }^{8,9,11}$ Briefly, neuronal death was confirmed qualitatively by examining cultures under phase-contrast microscopy and was quantified by measurement of LDH release from damaged cells into the bathing medium 24 hours after the onset of excitotoxin exposure. Only damaged cells (dead neurons) release LDH. LDH was measured by ELISA kit (Promega, Madison, Wis). The percentage of neuronal cell death was calculated by LDH levels in the bathing medium. The LDH level corresponding to complete neuronal death (without glial death) was determined in sister cultures exposed to $100 \mu \mathrm{mol} / \mathrm{L}$ NMDA. Background LDH levels were determined in sister cultures with sham wash as a control and subtracted from experimental values to yield the signal specific for experimentally induced injury. ${ }^{11}$

\section{Statistical Analysis}

The primary outcome measure for evaluating efficacy was percentage of neuronal cell death calculated by LDH levels. Results are expressed as mean \pm standard error. When $\mathrm{n}=12$ is indicated, this value corresponds to 12 different well pools derived from 3 different dissections. Analysis of these data included factorial 1-way analysis of variance with the Tukey post hoc method for multiple group comparisons to protect against type I (false-positive) results. ${ }^{12}$ The Statistical Package for the Social Sciences was used for statistical analysis (version 15.1; SPSS Inc, Chicago, Ill). Power analysis indicated that the sample sizes provided $80 \%$ power to detect a significant difference in neuronal cell death of $15 \%$ or more between treatment groups assuming a standard deviation of 5\% to $10 \%$ (version 7.0; nQuery Advisor, Statistical Solutions, Saugus, Mass).

\section{RESULTS}

Sham wash and addition of ibuprofen alone at the concentration of $100 \mu \mathrm{g} / \mathrm{mL}$ did not influence neuronal cells in either mixed or pure neuronal culture (Figure 1, $A, B$ ). Excitotoxicity was induced by exposure to $12.5 \mu \mathrm{mol} / \mathrm{L}$ NMDA or $50 \mu \mathrm{mol} / \mathrm{L}$ kainate for 24 hours and demonstrated an acute swelling of neuronal cell bodies followed by widespread necrotic neuronal degeneration resulting in disrupted neurons and segmentalized neurites in both near-pure and mixed cultures (Figure 1,C). Ibuprofen at a concentration of $100 \mu \mathrm{g} / \mathrm{mL}$ was co-applied in the medium with excitotoxin (NMDA). Ibuprofen was able to preserve neuronal cells, including neurites in both cultures (Figure 1, D). Exposure to $12.5 \mu \mathrm{mol} / \mathrm{L}$ NMDA revealed approximately $70 \%$ 
Exicitotoxicity by Kainate in Mixed Culture

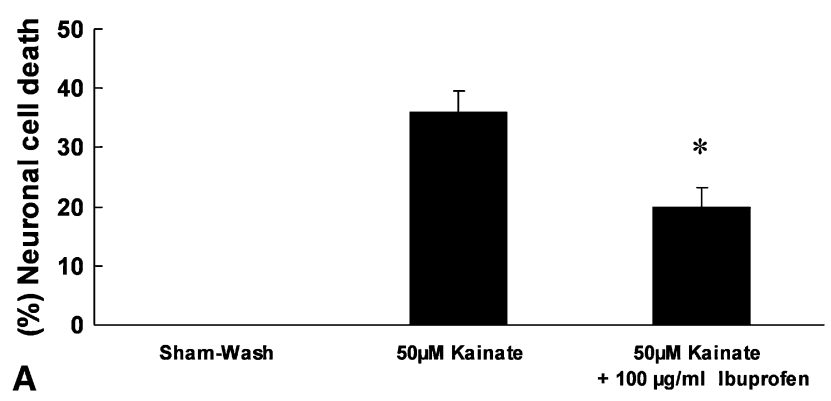

Exitotoxicity by Kainate in Near-Pure Culture

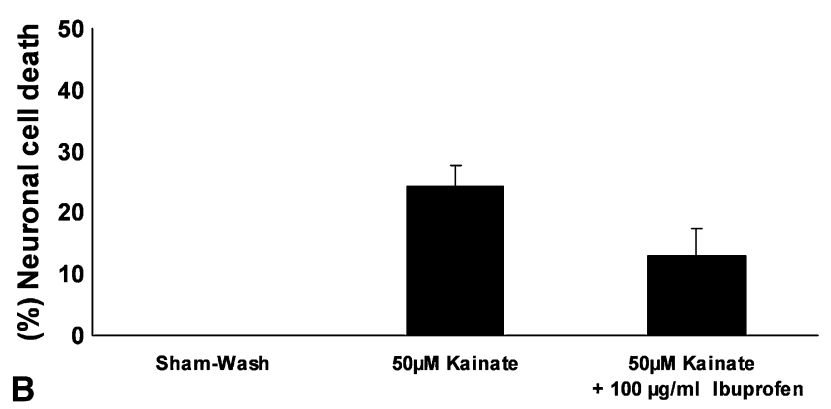

FIGURE 3. Exposure to $50 \mu \mathrm{mol} / \mathrm{L}$ kainate revealed approximately $30 \%$ neuronal cell death. Ibuprofen reduced neuronal cell death induced by exposure to $50 \mu \mathrm{mol} / \mathrm{L}$ kainate from $36.1 \% \pm 3.5 \%$ to $20.0 \% \pm 3.1 \%$ in mixed cultures but failed in near-pure cultures. A, Mixed cultures. B, Near-pure cultures. *Significantly different from kainate alone by analysis of variance with Tukey correction (mean \pm standard error).

neuronal cell death by LDH assay, measuring LDH levels in bathing medium in both cultures. Ibuprofen at a concentration of $25 \mu \mathrm{g} / \mathrm{mL}, 50 \mu \mathrm{g} / \mathrm{mL}$, and $100 \mu \mathrm{g} / \mathrm{mL}$ reduced neuronal cell death significantly from $74.5 \% \pm 3.8 \%$ to $56.1 \% \pm 4.0 \%, 38.7 \% \pm 2.8 \%$, and $12.3 \% \pm 1.4 \%$ in mixed cultures, respectively, revealing a strong dose-response $(P<.001)$. However, low-concentration ibuprofen failed to protect neurons in near-pure cultures (Figure 2, $A, B)$. Exposure to $50 \mu \mathrm{mol} / \mathrm{L}$ kainate revealed approximately $30 \%$ neuronal cell death. Ibuprofen also reduced neuronal cell death induced by exposure to $50 \mu \mathrm{mol} / \mathrm{L}$ kainate from $36.1 \% \pm 3.5 \%$ to $20.0 \% \pm 3.1 \%$ in mixed cultures but failed in near-pure cultures (Figure 3, $A, B$ ). These results suggest that ibuprofen may reduce glutamatergic excitotoxic neuronal cell death induced by NMDA or kainate, resulting from ischemia, although it may require interaction with glial cells.

\section{DISCUSSION}

This study demonstrated that ibuprofen protects neurons against glutamatergic excitotoxic neuronal cell death induced by NMDA or kainate in mixed cortical cultures. However, ibuprofen fails to reduce neuronal cell death in near-pure cultures. This result suggests that protection of neurons by ibuprofen requires interaction with glial cells and is not a result of a direct effect on neurons. Further evidence for the role of glial cells is the observation that the percentage of neuronal cell death was the same whether induced by NMDA or kainate in both cultures. It is possible that ibuprofen stimulates glial cells to release a neuroprotective mediator, such as a cytokine, or inhibits the deleterious effects of mediators released by glial cells.

It is thought that inflammation contributes to post-ischemic brain injury. Although cytokines are produced in the central nervous system by other cells, including astrocytes, neurons, and endothelial cells, microglia rapidly respond to injury by secreting inflammatory cytokines on injury. Proinflammatory cytokines, such as interleukin- $1 \beta$ and tumor necrosis factor- $\alpha$, are involved in ischemia/hypoxia and trauma-induced brain injury. ${ }^{13,14}$ Ibuprofen is a nonsteroidal anti-inflammatory drug and is widely used to reduce pain, fever, and inflammation. The drug inhibits cyclooxygenase and activates peroxisome proliferator-activated receptors; both of these actions result in reduced inflammation. $^{1-3}$ Park and coworkers ${ }^{5}$ described ibuprofen protecting neurons against ischemia via up-regulating interleukin-1 receptor antagonist expression. However, inhibition of cyclooxygenase has been controversial in adult cardiac surgery in regard to cardiac protection. McGuinness and coworkers ${ }^{15}$ reported that glutamine pretreatment conferred infarct protection through up-regulation of cyclooxygenase-2. Wong and colleagues ${ }^{16}$ reported that a selective cyclooxygenase-2 inhibitor did not affect the myocardium in patients undergoing coronary artery bypass grafting.

Local cerebral glucose use decreases after traumatic brain injury as live cells decrease in number. Pappius and Wolfe ${ }^{6}$ demonstrated that pretreatment with ibuprofen prevented the depression of local cerebral glucose use after traumatic brain injury. They suggested that ibuprofen protected neurons and improved cerebral metabolism after brain injury and that these effects might be associated with suppression of prostaglandin synthesis.

Cerebral blood flow usually decreases after cerebral ischemia because of vasoconstriction resulting from hypoperfusion during ischemia and subsequent inflammation. Grice and colleagues ${ }^{7}$ reported that ibuprofen improved post-ischemic hypoperfusion after normothermic global cerebral ischemia in dogs, although cerebral blood flow did not return to normal. They demonstrated that ibuprofen suppressed the production of thromboxane B2 and prostaglandin I2 after global cerebral ischemia. ${ }^{7}$ Ibuprofen has been reported to reduce infarct size after temporary cerebral ischemia, for example, after deep hypothermic circulatory arrest. ${ }^{4}$ They suggested that the beneficial effect of cyclooxygenase inhibition occurs during reperfusion. 


\section{CONCLUSIONS}

Ibuprofen provides neuroprotection through glial cells against glutamatergic excitotoxicity as demonstrated by reduced neuronal cell death in mixed cell cultures. Further studies regarding mechanisms at the molecular level and with whole animal models are needed to assess the potential of ibuprofen to reduce neurologic injury in patients undergoing circulatory arrest and cardiopulmonary bypass.

\section{References}

1. Kaufmann WE, Andreasson KI, Isakson PC, Worley PF. Cyclooxygenases and the central nervous system. Prostaglandins. 1997;54:601-24.

2. Lehmann JM, Lenhard JM, Oliver BB, Ringold GM, Kliewer SA. Peroxisome proliferator-activated receptors alpha and gamma are activated by indomethacin and other non-steroidal anti-inflammatory drugs. J Biol Chem. 1997;272: 3406-10.

3. Kojo H, Fukagawa M, Tajima K, Suzuki A, Fujimura T, Aramori I, et al. Evaluation of human peroxisome proliferator-activated receptor (PPAR) subtype selectivity of a variety of anti-inflammatory drugs based on a novel assay for PPAR delta (beta). J Pharmacol Sci. 2003;93:347-55.

4. Cole DJ, Patel PM, Reynolds L, Drummond JC, Marcantonio S. Temporary focal cerebral ischemia in spontaneously hypertensive rats: the effect of ibuprofen on infarct volume. J Pharmacol Exp Ther. 1993;266:1713-7.

5. Park EM, Cho BP, Volpe BT, Cruz MO, Joh TH, Cho S. Ibuprofen protects ischemia-induced neuronal injury via up-regulating interleukin-1 receptor antagonist expression. Neuroscience. 2005;132:625-31.
6. Pappius HM, Wolfe LS. Effects of indomethacin and ibuprofen on cerebral metabolism and blood flow in traumatized brain. J Cereb Blood Flow Metab. 1983;3:448-59.

7. Grice SC, Chappell ET, Prough DS, Whitley JM, Su M, Watkins WD. Ibuprofen improves cerebral blood flow after global cerebral ischemia in dogs. Stroke. 1987; 18:787-91.

8. Choi DW. Excitotoxic cell death. J Neurobiol. 1992;23:1261-76.

9. Rose K, Goldberg MP, Choi DW. Cytotoxicity in murine cortical cell culture. In: Tyson CA, Fraizer JM, eds. Vitro Biological Methods. San Diego, CA: Academic Press; 1993:46-60.

10. Konstan MW, Byard PJ, Hoppel CL, Davis PB. Effect of high-dose ibuprofen in patients with cystic fibrosis. N Engl J Med. 1995;332:848-54.

11. Koh JY, Choi DW. Quantitative determination of glutamate mediated cortical neuronal injury in cell culture by lactate dehydrogenase efflux assay. $J$ Neurosci Methods. 1987;20:83-90.

12. Motulsky H. Intuitive Biostatistics. New York: Oxford University Press; 1995: 255-67.

13. Sawada M, Kondo N, Suzumura A, Marunouchi T. Production of tumor necrosis factor-alpha by microglia and astrocytes in culture. Brain Res. 1989;491: 394-7.

14. Saito K, Suyama K, Nishida K, Sei Y, Basile AS. Early increases in TNF-alpha, IL-6 and IL-1 beta levels following transient cerebral ischemia in gerbil brain. Neurosci Lett. 1996;206:149-52.

15. McGuinness J, Neilan TG, Cummins R, Sharkasi A, Bouchier-Hayes D, Redmond JM. Intravenous glutamine enhances COX-2 activity giving cardioprotection. J Surg Res. 2008 Apr 28 [Epub ahead of print].

16. Wong PS, Asmat A, Chan YH, Lee CN. A randomized, double-blind, placebocontrolled trial of a COX-2 inhibitor (Rofecoxib) in patients undergoing coronary artery bypass surgery. Interact Cardiovasc Thorac Surg. 2006;5:101-4. 